\title{
EXPERIMENTAL STUDY OF RE-ESTABLISHMENT OF PERIPHERIAL BLOOD FLOW AFTER LIGATION OF EXTERNAL CAROTID ARTERY
}

By

HiRosh HAMANOUE

\author{
From the Department of Oto-Rhino-Laryngology, Tokyo Women's \\ Medical College. (Director: Prof. H. Iwamoto)
}

Ligation of the external carotid artery is not infrequent operation now, and every surgeon today has performed or has had been acquainted with the surgery of this vessel.

It is commonly believed that the peripherial blood flow after the ligation of external carotid artery is reduced or ceased for a long time, but concerning this, only a few experiments about reestablishment of the blood flow after the ligation have been made.

Therefore, the re-establishment of blood flow was observed in man by using a plethysmograph and sphygmo-manometer and by using the three dimensional cast model of the blood vessel in the dog.

1) Re-establishment of the blood flow

The plethysmograph at the ear lobe showed that in 11 of the 18 cases $(61 \%)$ the blood flow was recovered in 5 days, that is, in 4 of 11 immediately after the ligation, 3 in 1 day, 1 in 3 days, 3 in 5 days. And also immediately after the ligation low but regular waves were noted.

2) Blood pressure

Blood pressure of the external carotid artery was messured befor and after the ligation in 4 cases in man and 6 cases in dog, and arterial pressure was maintained on the same level as venous pressure.

3) Anastomosis

Three dimensional cast model in dogs showed the most important channel of collateral circulation to the external carotid artery were the exter. nal ophthalmic artery and middle meningial artery and following this the free communication between the external carotid arteries of both sides and the vertebral artery into the occipital artery. Moreover, the route of the ophthalmic artery to the external ophthalmic artery and the ethmoidal artery to the external ophthalmic artery were recognized, but it is thought that the route does not contribute to the blood flow because of its narro. wness.

Results.

The re-establishment of the blood flow was much earlier than it was thought and the arterial pressure was maintained on the same level as the venous pressure, so one should not rely too much on the ligation of the external carorid artery for control of hemorrhage. 


\title{
外形動脈結紮後の末梢血行回復についての実験的研究
}

\author{
東京女子医科大学耳算咽喉科教室（主任：岩本彦之西教授）
}

$$
\text { 浜立 卡洋 }
$$

\section{目次}

I緒言ならびK研究目的

1 眽波測定による研究

1. 研究方法

a) 装管

b) 湘定方法及び条件

2. 実験成綪

3. 小 括

III血生測定に上る研究

1. 研乫方法

2. 実験成路

3.小括

N アフリル樹脂による血管模型による研笔

1. 唧㭝目的

2. 研究方法

3. 実験成綪

4. 小 括

V皮フ温测定による奏験

月考策

17 結 語

VII 女文献

\section{I. 鍺言ならひに研究目的}

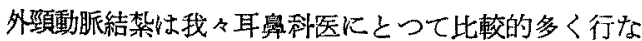
われる術式の一つであり，何らかの形でこれに関与しな いものはないであるう．この術式の適応はたとえば鼻出 If，頙頸部の術後性出血，術中出血の子防または軽隇な どのように種々多様であるが，その目的は一つでいずれ も血管を結紮することによりその支配領域への血行を遮 㬗することにある、しかし結禁後の末梢血流がどのよう に変化するものであららか，極端に言つて血行が全く停 止してしま5むのか，あるいはまた血行がいくらか牫つ ているすのとしてもど程度のもので，それはどこから 流入してくるものたろらか。この方面に打ける研究は非 常に少なく，多くは臨床的な経飨や推測に止まつてい るそそこで著者は人において光電容積脈波計，電気血纴 計，温度サーミスターを用いて生理学的に血行回復につ
いて䅐察し，一方犬に括いてはその他にアクリル樹脂を 血管に注入して解剖学的に検索を行ないその副血行を知 ろらとした。

\section{I. 脈波測定による研究}

1. 研究方法
a) 装
琶

末梢血流を測定するには種々の方法があるが，その中 で光電現象を利用した容積脈波検查は，1）検查が簡便 なこと，2）物理化学的または機械的影響を生体に与党 ることが少ない，3）被検者に心理的負荷を与之ない。 などの理由で最近次第に臨床実験に使用されるようにな つてきた.

その中でも Cad 光導電体を光電管として利用したも

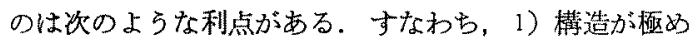
て軽量小型，2）耐湿，3）極めて高感度で徽䋖な変化を 追求できる，4）電極間に極性がない，5）直流，交流両 回路に使用することがでさる，6）光電管感度曲線は第， 1 図に示すように赤血球の波長（酸化 $\mathrm{Hb} 504$ 澧元 $\mathrm{Hb}$ $560 \mathrm{~m} \mu$ ) のところで最も敏感であり，その部分では大体

図 $1 \mathrm{Cds}$ 分光感度曲線

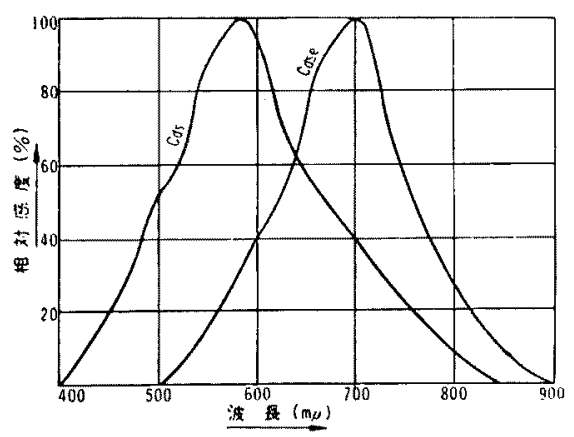

直線と見なされるので波高の高低により血液量の多少を 諭ずることができると思われる，7）温度特性は加藤 ${ }^{15)}$ によるとフンプによる温度や生体の温度程度では出力に

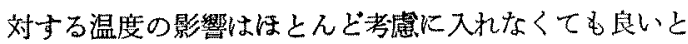
W5. 
莮録用へッドは耳垂に装着するのに便利なように軽量 小型のヘッドを作製した，そして図2のごとく連結され る.

写 真 1 記録用ヘッド括よび前叠增巾器

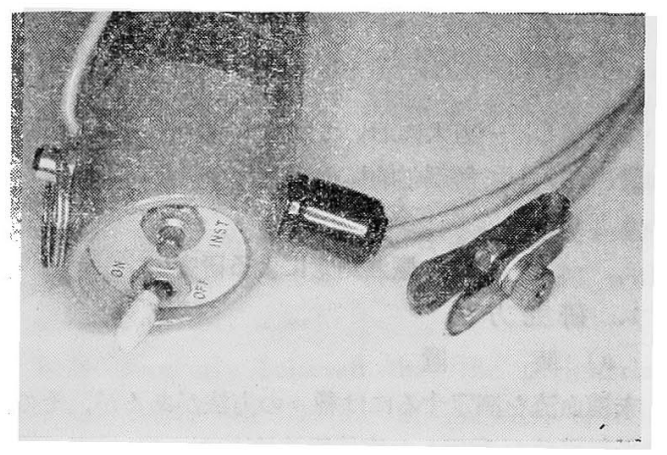

写 真 2 万能記録計

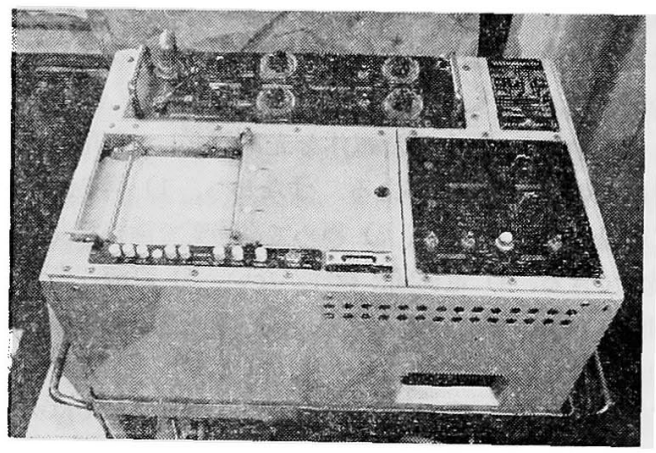

図2

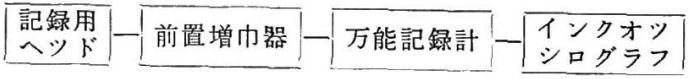

b）測定方法及び測定条件

耳垂末梢血流は種々の条件で変動するので22)9116)なる ベく血流状態を一定にするように心がけた。すなわち，

1）なるべく心理的，機械的な影響を与えないために 装着後 10 分後より記録を開始した。

2）記録用ヘッドの装著部位の位置のずれにより波 型，波高が变化するので硝酸銀その他のマークにより装 着位置を一定にした。

3）装着時の耳垂の圧迫程度により波高が変化するの でヘッドのとりつけネジを一定回転することにより（落 ちないように最も弱い）圧を一定にした。

4）測定時間も一定時間に測定することが望ましいが
室温，照度などは病室で行なつた結果，必ずしも同じ条 件にはならなからた。

5）患者の状態，たとえば血圧，発熱などによつてる 条件が変化するので左右同じへッドで測定し左右比を回 復の一番のめやすとした。

血行回復の判定

血行回復の判定は波高によつたが，以上の上うに種々 の条件で波高が変化するので，波高の実測値をもつてそ のまま血行回復の判定に用いることはできない，たと党 ば表1のような場合，一日後において左右之も3で等し くなつているが，結紮前のものと比較するとまだ回復し たとは言えない，二日目を見て見ると，左は結紮前の $1 / 2$ と低下してまだ回復せずむしろ一日後の3の方が回 復てしいるよらに見觉るが，左右をくらべて見ると 2 日 後に执いて同じ割合で低下しているので回復は 2 日後と 言える.

\begin{tabular}{|c|c|c|c|c|}
\hline & & & 右 & 压 結紫湖 \\
\hline 結 & 禁 & 前 & 2 & 4 \\
\hline 結 & 禁 & 後 & 4 & 0 \\
\hline 1 & 日 & 後 & 3 & 3 \\
\hline 2 & 日 & 後 & 1 & 2 \\
\hline
\end{tabular}

単位 $\mathrm{mm}$

2. 実験成絃

外頸動脈結紮を行なつたのは 30 例でその内雨側に利 いて測定を行なつたるのは 18 例である.

\begin{tabular}{rll||rrr|rrr}
\hline \multicolumn{2}{c|}{ No. } & 1 & \multicolumn{3}{c|}{ 右 } & \multicolumn{3}{|c}{ (在) } \\
\hline \hline 結 & 势 & 前 & 4 & 9 & 18 & 3.5 & 7 & 14 \\
結 & 禁 & 後 & 3 & 6 & 12 & 2 & 4 & 10 \\
2 & 日 & 後 & 1.5 & 3 & 7 & 1.5 & 3 & 7 \\
3 & 日 & 後 & 1.5 & 3.5 & 7 & 4 & 10 & 22
\end{tabular}

○は結禁側を示寸

判定：結森後ですでに

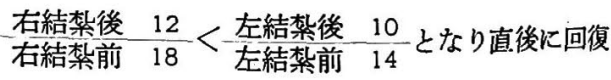
している例である. 図 3 参照. 
図 3 結 紫 直後回復 例

右左結紫侧

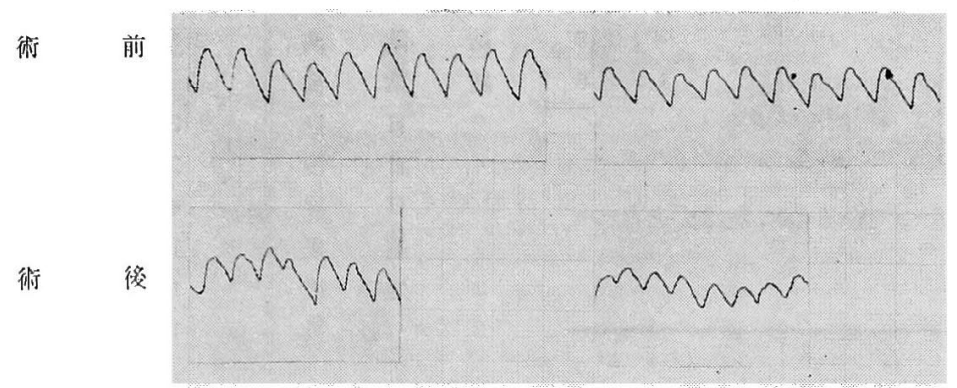

\begin{tabular}{rll||rrr|rrr}
\hline \multicolumn{2}{c|}{ No. } & 2 & & (右) & \multicolumn{3}{|c|}{ 左 } \\
\hline \hline 結 & 禁 & 前 & 13 & 25 & - & 2 & 5 & 11 \\
結 & 禁 & 後 & & - & & 0.5 & 1 & 2 \\
1 & 日 & 後 & 1 & 2 & 5 & 1 & 2.5 & 5 \\
2 & 週 & 後 & 1 & 2 & 5 & 1 & 2 & 5
\end{tabular}

判定：1日以後に就いて左右等しい值を示すが結杽 前と比較すると右は非常に小である. 判定に迷ら例で不 明例とする.

\begin{tabular}{ccc||rrr|rrr}
\hline & No. & 3 & & 右 & \multicolumn{3}{|c}{ (左) } \\
\hline \hline 結 & 紧 & 前 & 2 & 5 & 10 & 5 & 10 & 16 \\
1 & 日 & 後 & 18 & 34 & - & 2 & 4 & 8 \\
10 & 日 & 後 & 2.5 & 5 & 10 & 1.5 & 4 & 8
\end{tabular}

判定：10日後において右は術前と等しくなつている が左はまだ $1 / 2$ である。10日後回復せず.

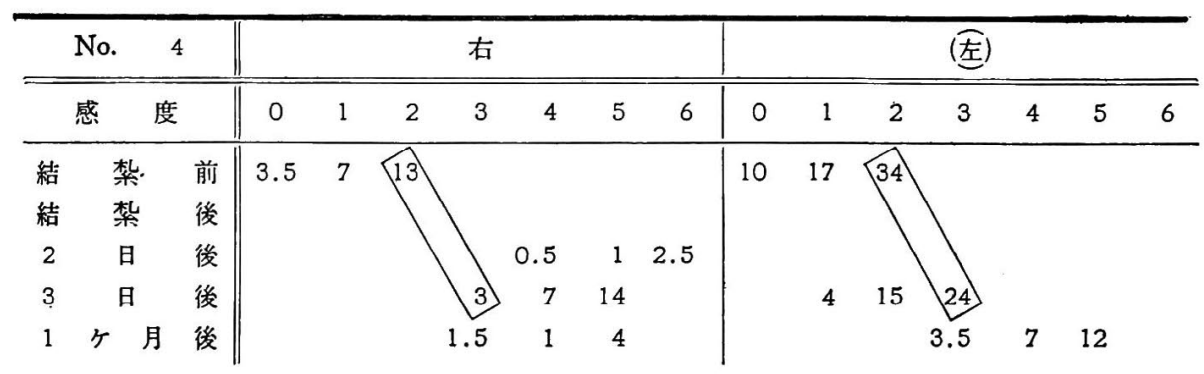

判定：非常にぱらつきの多い例であるが，3 日後の左 $24 / 34$ に比し右 $3 / 13$ は非常に 小で結紮側の方が大となつ ている. 3 日後回復例.

\begin{tabular}{ccc||rr|rr}
\hline No. & 5 & \multicolumn{2}{c||}{ (否) } & \multicolumn{3}{|c}{ 左 } \\
\hline \hline 結 & 禁 & 前 & 7 & 11.5 & 4 & 7 \\
結 & 禁 & 後 & 0.5 & 1 & 2 & 4 \\
3 & 日 & 後 & 6.5 & 11.5 & 1 & 1.5
\end{tabular}

判定：左 $1.5 / 7$ に対し右 $11.5 / 11.5$ で結紮側の方が 大となつている. 3 日後回復例.

\begin{tabular}{lll||rrr|rrr}
\hline No. & \multicolumn{1}{c||}{6} & \multicolumn{3}{c|}{ 右 } & \multicolumn{3}{|c|}{ (左) } \\
\hline \hline 結 & 禁 & 前 & 5 & 9 & 15 & 6 & 11 & 23 \\
結 & 禁 & 後 & 6.5 & 14 & 28 & 7 & 13 & \\
4 & 日 & 後 & 3 & 5 & 14 & 1 & 2 & 5 \\
6-91 & & & & & & & &
\end{tabular}

判定：術後は術前より波高大となつているが 左の方 が增加率小でまだ回復せず，4 日後では明らかに左小で ある. 4 日以降回復例.

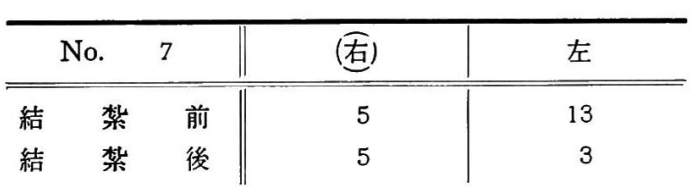

判定：結紮後左は波高が低下しているのに右は等し い波高を示す. 術直後回復例. 


\begin{tabular}{|c|c|c|c|c|c|c|}
\hline & & 8 & \multicolumn{3}{|c|}{ 右 } & (在) \\
\hline 結 & 奖 & 前 & 5 & 10 & 19 & 125 \\
\hline 絬 & 禁 & 後 & 0.5 & I & 2 & 1.536 \\
\hline 1 & 日 & 後 & 2 & 4 & 8.5 & 5816 \\
\hline
\end{tabular}

判定：術後右は小となつているのに左は大となつて いる. 結紮直後回復例。

\begin{tabular}{ccc||rr|rr}
\hline & No. & 9 & \multicolumn{2}{|c|}{ 右 } & \multicolumn{2}{|c|}{ (在) } \\
\hline 結 & 㷊 & 前 & 4 & 9 & 8 & 17.5 \\
結 & 禁 & 後 & 5 & 9 & 7 & 10 \\
1 & 日 & 後 & 6 & 10 & 7 & 15
\end{tabular}

判定：一日後ほぼ回復したと言える。一日後回復例.

\begin{tabular}{|c|c|c|c|c|c|}
\hline & & 10 & 右) & & 左 \\
\hline 結 & 紫 & 前 & $\begin{array}{lll}8 & 11 & 23\end{array}$ & 7 & 16 \\
\hline 結 & 紫 & 後 & 36.518 .5 & 2 & . 6 \\
\hline 2 & 日 & 後 & 1322.5 & 5.5 & 17 \\
\hline
\end{tabular}

判定：2 日位では明らかに右が大，結禁直後では 18.5/23>6/16 で右が大きい. 術直後回復例.

\begin{tabular}{ccc||rr|rr}
\hline \multicolumn{2}{c|}{ No. } & 11 & (若) & \multicolumn{2}{|c}{ 左 } \\
\hline \hline 結 & 禁 & 前 & 4 & 8 & 12 & 25 \\
結 & 紧 & 後 & 3 & 6 & 23 & 46 \\
5 & 日 & 後 & 0.5 & 1 & 2 & 4 \\
12 & 日 & 後 & 0.5 & 1 & 1.5 & 2
\end{tabular}

判定：12日後右 $0.5 / 4=$ 左1.5/12 となり 12 日後回 復したと言える。12日後回復例。

\begin{tabular}{lll||rrr|rr|r}
\hline & No. & 12 & \multicolumn{3}{|c|}{ 右 } & \multicolumn{3}{|c|}{ (在) } \\
\hline \hline 結 & 禁 & 前 & 5 & 10 & 23 & 3 & 7.5 & 17 \\
結 & 禁 & 後 & 2 & 4 & 5 & & 1 & 3 \\
1 & 日 & 後 & 1.5 & 3 & 7 & & 3 & 8
\end{tabular}

判定：一日後右 $3 / 10<$ 左 $3 / 7.5$ で左の 回復率が大. 一日後回復例. 因 4 参照.

\begin{tabular}{|c|c|c|c|c|c|c|}
\hline \multicolumn{2}{|c|}{ No. } & 13 & \multicolumn{2}{|c|}{ (菫 } & \multicolumn{2}{|c|}{ 左 } \\
\hline 結 & 紫 & 前 & 2.5 & 5 & 2 & 4 \\
\hline 䋨 & 紫 & 绻 & - & - & - & - \\
\hline 2 & 日 & 後 & 2 & 4 & 7 & 13 \\
\hline 4 & 日 & 後 & 2 & 4 & 7 & 14 \\
\hline 10 & 日 & 後 & 4 & 8 & 5 & 9 \\
\hline 2 & 週 & 後 & 1 & 3 & 3 & 6 \\
\hline 3 & 週 & 後 & 1 & 3 & 3 & 5 \\
\hline 3 & r & 後 & 1 & 2 & 2 & 4 \\
\hline
\end{tabular}

判定：3ヶ月で回復しない例. 図6参照.

\begin{tabular}{lll||rrr|rrr}
\hline & No. & 14 & \multicolumn{3}{|c|}{ 在 } & \multicolumn{3}{|c}{ (在) } \\
\hline \hline 結 & 樂 & 前 & 5 & 11 & 23 & 2.5 & 6.5 & 16 \\
結 & 㭔 & 後 & 2 & 3 & & 0.5 & & \\
1 & 日 & 後 & 2 & 5 & 17 & 2 & 4 & 9
\end{tabular}

判定： 1 日後右 $2 / 5<$ 左 $2 / 2.5$ で結禁側が大. 一日後 回復例.

\begin{tabular}{|c|c|c|c|c|c|c|}
\hline & & 15 & \multicolumn{2}{|c|}{ 右 } & \multicolumn{2}{|c|}{ (左) } \\
\hline 結 & 禁 & 前 & 4 & 10 & 2.5 & 5 \\
\hline 1 & 日 & 後 & 12 & 22 & 2.5 & 5 \\
\hline 2 & 日 & 後 & 6 & 12 & 2 & 5 \\
\hline 5 & 日 & 後 & 4 & 8 & 25 & 5 \\
\hline
\end{tabular}

判定：2 日後頃から大体回復しかけているが5 日後 ではすでに回復は完了している.5 日後回復例. 图5参 照.

\begin{tabular}{ccc||rr|rr}
\hline No. & 16 & \multicolumn{3}{|c|}{ (看) } & \multicolumn{2}{|c}{ 左 } \\
\hline \hline 結 & 禁 & 前 & 5 & $\mathbf{1 0}$ & 4 & $\mathbf{6}$ \\
結 & 紫 & 後 & 0.5 & $\mathbf{1}$ & 3 & $\mathbf{6}$ \\
3 & 日 & 後 & 1 & $\mathbf{2}$ & 1 & $\mathbf{2}$ \\
25 & 日 & 拺 & 3 & $\mathbf{5}$ & & $\mathbf{4}$
\end{tabular}

判定：3 日後大体回復している. 3 日後回復例. 

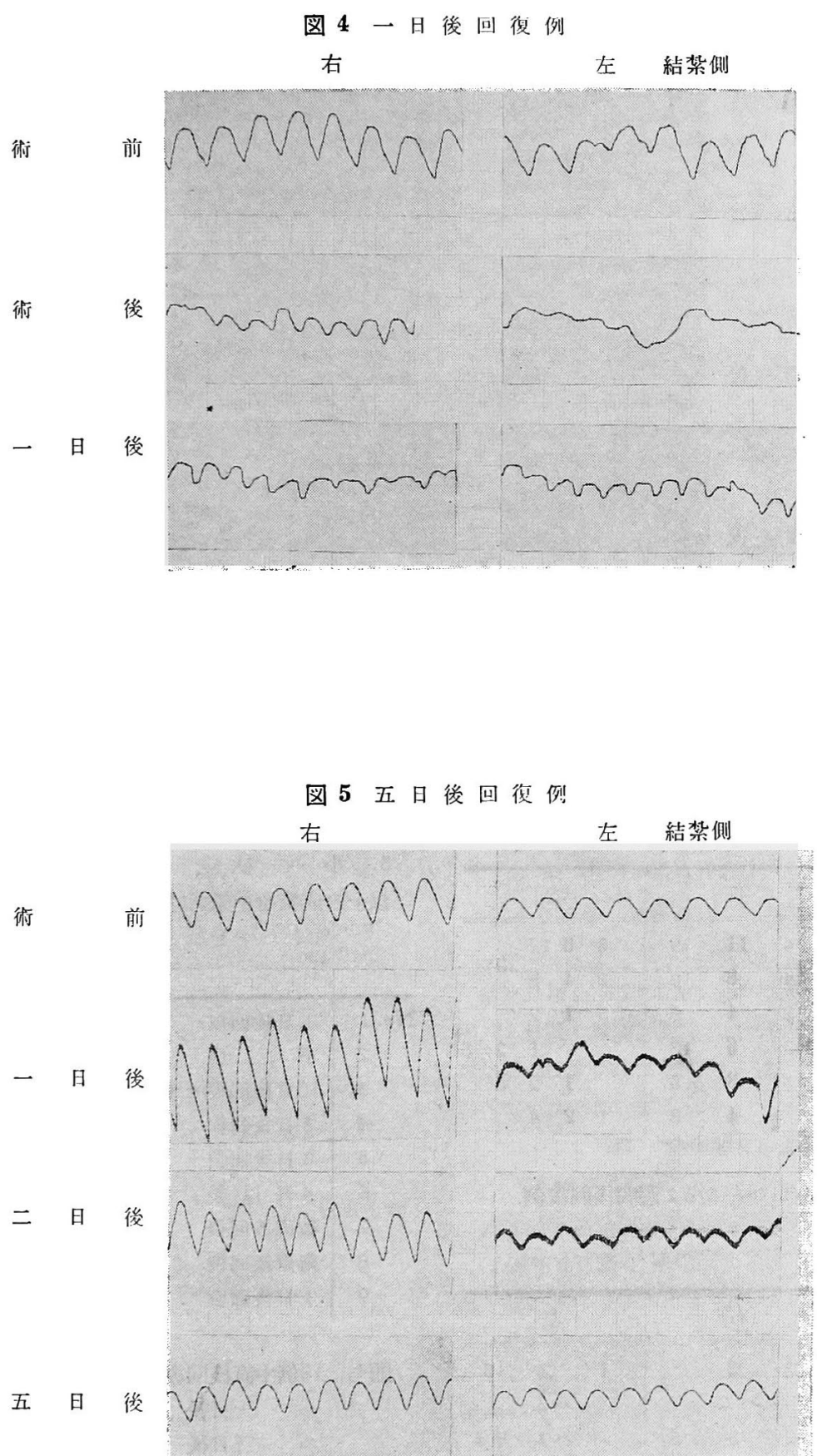
图 6 三ヶ月で回復しない例

右結紫僛左

術

前

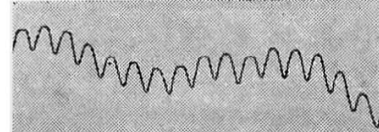

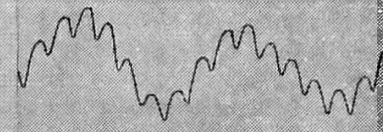

二日後

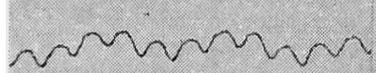

थी

二 週 後

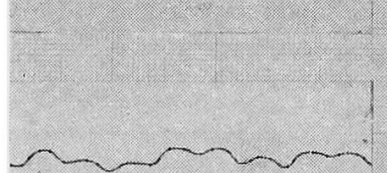

三 週 後

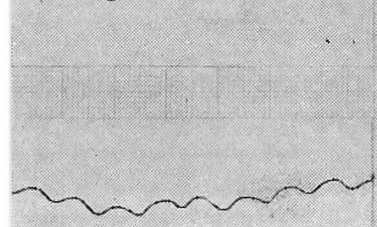

三ヶ 月 後

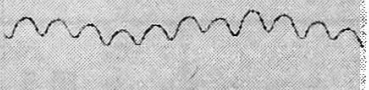

\begin{tabular}{|c|c|c|c|c|c|c|c|c|c|}
\hline \multicolumn{2}{|c|}{ No. } & 17 & \multicolumn{3}{|c|}{ 右 } & \multicolumn{4}{|c|}{ (左) } \\
\hline 結 & 禁 & 前 & 4 & 11 & 19 & 3 & & 12 & \\
\hline 結 & 禁 & 後 & 4 & 8 & 18 & 2 & 4 & 8 & \\
\hline 1 & 日 & 後 & 2 & 4 & 8 & 0.5 & 1 & 2 & \\
\hline 3 & 日 & 後 & 2.5 & 6 & 13 & & & 1 & 25 \\
\hline 1 & 週 & 後 & 1 & 3 & 5.5 & & 1 & 2 & 5 \\
\hline 2 & 週 & 後 & & 4 & 8 & 1 & 2 & 4 & \\
\hline
\end{tabular}

判定： 2 週間後右 $4 / 11 \fallingdotseq$ 左 $2 / 62$ 週間後回復例.

\begin{tabular}{|c|c|c|c|c|c|c|c|c|}
\hline & & 18 & \multicolumn{3}{|c|}{ (石) } & \multicolumn{3}{|c|}{ 左 } \\
\hline 結 & 禁 & 前 & 2 & 3 & & 1 & 2 & 5 \\
\hline 結 & 禁 & 後 & & $\Delta$ & & & 八厶 & \\
\hline 1 & 週 & 後 & 2 & 3 & 5 & & 八厶 & \\
\hline
\end{tabular}

判定： 1 週間後回復例.
3. 小 括

以上の成績を結果だけまとめると下表のようになる。

\begin{tabular}{r|l||r|l}
\multicolumn{9}{c|}{$\mathbf{2}$} \\
\hline No. 1 & 1 日後回復 & No.10 & 術直後回復 \\
2 & 不 $\quad$ 明 & 11 & 12 日後回復 \\
3 & 10日後回復せず & 12 & 1 日後回復 \\
4 & 3 日後回復 & 13 & 3 ケ月で回復せす \\
5 & 3 日後回復 & 14 & 1 日後回復 \\
6 & 4 日 以 後 & 15 & 5 日以内に回復 \\
7 & 術直後回復 & 16 & 約 3 日後回復 \\
8 & 術直後回復 & 17 & 2 週間後回復 \\
9 & 1 日後回復 & 18 & 1 週間後回復
\end{tabular}

即ち, 18例中直後回復例 3 例

$$
\left.\begin{array}{ll}
\text { 一日後 } & 4 \\
\text { 三日後 } & 3 \\
\text { 五日後 } & 1
\end{array}\right\} 11 \text { 例 } \quad \text { 約 } 60 \%
$$

となり，約60\%は五日以内に回復したと言える.そして 
全例とも結禁直後においてさ克，小ではあるが規側正し い眽波をすで示し，かなりの血行のあることを示して いる。以上両側耳垂で脈波を測定した例で見ると脈波の 波高がかなり種々の条件でばらつくことが判り，両側を 測定することによつてかららじて血流回復の判定を下す ことができると思われる。

以前飞測定していた一側計測例と比較してみよう。こ の場合の回復判定の莹準は，波高が結紮前と同じ高さに なったときをむつて回復の基準とした。

\begin{tabular}{|c|c|c|c|c|c|}
\hline & & 1 & & & \multirow{4}{*}{2 日後问得 } \\
\hline 結 & 紮 & 湔 & 6 & 3 & \\
\hline 結 & 禁 & 後 & 2 & & \\
\hline 2 & 日 & 後 & 7 & 15 & \\
\hline
\end{tabular}

\begin{tabular}{|c|c|c|c|c|c|}
\hline \multicolumn{2}{|c|}{ No. } & 2 & & & \multirow[b]{3}{*}{ 12日後で国街 } \\
\hline 絈 & 嫊 & 前 & 9 & 19 & \\
\hline 結 & 柇 & 徭 & 1.5 & & \\
\hline 1 & 日 & 後 & 1 & 2 & 世毕 \\
\hline 2 & 日 & 㷋 & 1.5 & 3 & \\
\hline 1 & 週 & 後 & 2 & 3.5 & \\
\hline 12 & 日 & 後 & 1 & 2 & \\
\hline
\end{tabular}

\begin{tabular}{|c|c|c|c|c|}
\hline \multicolumn{2}{|c|}{ No. } & 3 & & \\
\hline 結 & 禁 & 前 & 22 & \\
\hline 結 & 紮 & 後 & 1 & 6日で回復せす \\
\hline 3 & 日 & 後 & 0 & \\
\hline 4 & 口 & 後 & 2 & \\
\hline 6 & 日 & 後 & 6 & \\
\hline
\end{tabular}

\begin{tabular}{lll||r}
\hline \multicolumn{2}{c||}{ No. } & \multicolumn{1}{c||}{4} & \\
\hline \hline 結 & 紧 & 前 & 13 \\
結 & 紫 & 後 & 7 \\
22 & 日 & 後 & 5 \\
29 & 日 & 後 & 8
\end{tabular}

\begin{tabular}{ccc||c}
\hline & No. & 5 & \\
\hline 結 & 禁 & 前 & 7 \\
結 & 禁 & 後 & 0 \\
1 & 日 & 後 & 5
\end{tabular}

29日後で回復しな W

1日でほぼ回復

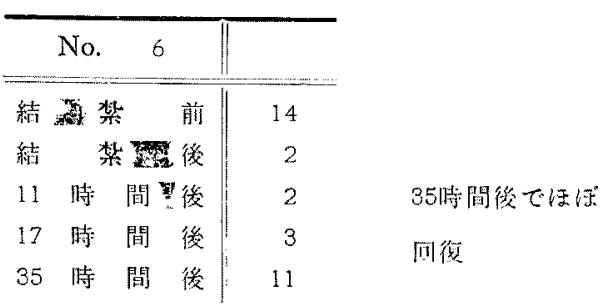

\begin{tabular}{|c|c|c|c|c|}
\hline & & 7 & & \multirow{5}{*}{2 日で同復せ心 } \\
\hline 絬 & 禁 & 前 & 14 & \\
\hline 結 & 紫 & 後 & 1 & \\
\hline 1 & 日 & 啳 & 10 & \\
\hline 2 & 日 & 後 & 7 & \\
\hline
\end{tabular}

\begin{tabular}{|c|c|c|c|c|}
\hline & & 8 & & \\
\hline 結 & 慗 & iij & 7 & \\
\hline 結 & 禁 & 後 & 1 & 2 日でゃゃ国彻 \\
\hline 1 & 日 & 骁 & 4 & \\
\hline 2 & 日 & 後 & 5 & \\
\hline
\end{tabular}

\begin{tabular}{ccc|r}
\hline No. & 9 & \\
\hline 絬 & 梦 & 前 & 23 \\
結 & 㷊 & 後 & 3 \\
2 & 日 & 後 & 5 \\
3 & 日 & 後 & 6 \\
4 & 日 & 後 & 8
\end{tabular}

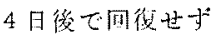

結禁值媵回復例はなく，1日後浪ぼ回復したもの1 例，2 日後で注湆回復したもの3例で，5 日以内に回復 したものは 9 例中 4 例 $44 \%$ となり，両側測定のものにく らべてかなり低い值になる。

\section{III、血圧測定による研究}

1. 研究方法

外頸動脈結紮部末梢の血圧を測定するために人に括い ては電気血圧計を使用して針先を末梢に向けて計測し た、そのブロックダイフグラムは図7のごとくである.

図 7 電気血圧計ブロックダイアグラム

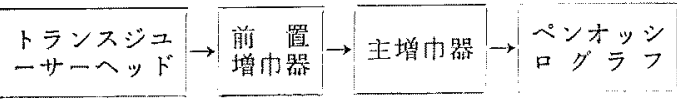


写真 3 犬用组压部

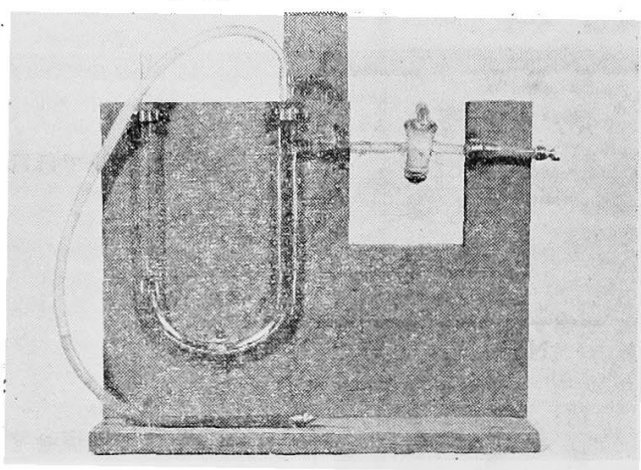

犬に批いて壮写真 3 のごとき水銀血圧計を作製し，日 をおいて血圧を測定した。血圧は結禁時な捄約 $20 \mathrm{mgHg}$ 高い圧を示し，除々に低下して約 5 分位で平衡状態にな るので測定は 5 分以後に行なつた.

図 8 外頸 動 脈 圧 結 紮 前 結 柴 後

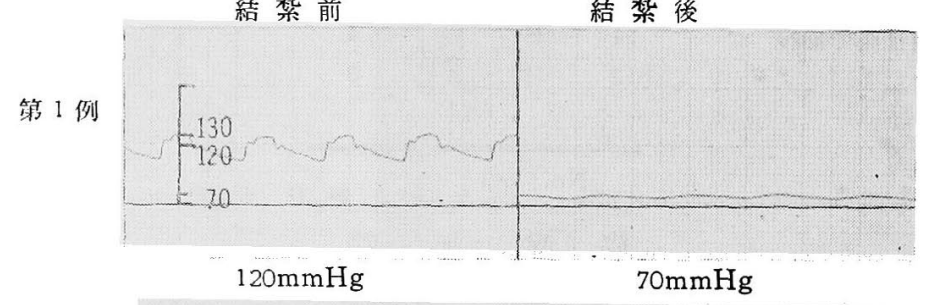

第 2 例

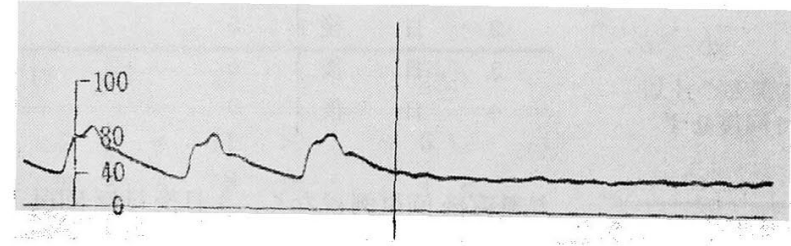

$85 \mathrm{mmHg}$
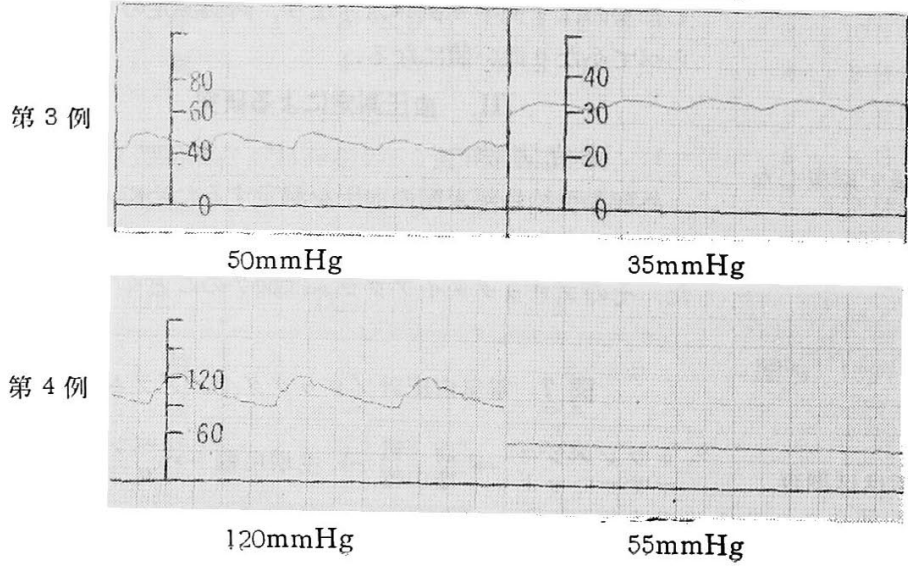

表 $\quad 3$

\begin{tabular}{|c|c|c|c|c|c|c|}
\hline & & 結 & 禁 前 & & 紫 後 & ○日 後 \\
\hline No. & 1 & & $43 \mathrm{mg}$ & & 26 & $\begin{array}{c}36 \\
72 \text { 日後 }\end{array}$ \\
\hline No. & 2 & & 29 & & 22 & \multirow{5}{*}{$\begin{array}{c}26 \\
30 \text { 日後 }\end{array}$} \\
\hline No. & 3 & & 38 & & 20 & \\
\hline No. & 4 & & 27 & & 15 & \\
\hline No. & 5 & & 38 & & 19 & \\
\hline No. & 6 & & 35 & & 10 & \\
\hline
\end{tabular}

2. 実験成 蹟

人は 4 例に行ない, いづれも術前の約半分の圧, 静脈 圧程度を維持している. 図8 参照.

犬は 6 例に行ないその成績は表 3 のごとくである.

大体人と同じ傾向を示し動脈王が静脈圧程度に低下し 次第に回復して 30 日後，72 日後の血圧はほぼ結禁前の 血王に戾つている.

\section{3. 小 括}

結紮後の外頸動脈末梢圧は普通，零ま たはそれに近い値を示すと考えがちであ るが，人，犬とも思つたよりも高い圧， 静脈圧程度の圧を維持し, またその操作 中でも末梢血管は明らか《脈動している ことが観察される. そして犬に拈いて30 日後，72 日後の压は結紮前の航王上り は多少低いが活等しい圧まで回復して いる.

\section{IV．アクリル樹脂血管模型 \\ による研究}

\section{1. 研究目的}

以上脈波計，血压計による測定より結 禁直後といえどもかなりの血行を維持 し, その回復もかなり早い時期であるこ とが判つたが，ではこれらの血行はどこ から，どの副血行を通つてくるのであろ うか?この問題を知るためにアクリル樹

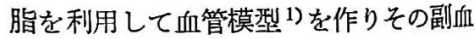
行を知ろらとした。

2. 研究方法

使用動物は猿が理想的であろうが，今 回は種々の都合で $10 \mathrm{~kg}$ 前後の雄犬を使 用した。その犬の外頸動脈を結紮し日を おいて，再び頸動脈を露出し，10\%クエ 
ン酸ナトリウムを約 20cc 注入して屠殺し，直ちに調製 したアクリル樹脂を毛細血管を目標にしながら压入す る. 一日後に $20 \%$ 苛性ソーダの入つたガラス槽に入れ 4 5 日間放置. 4〜 5 日後に石ケン化した頭部を水また は㠎温湯にて洗い流して血管模型を得る.アクリル樹脂 謌製の実際について簡単に述べる.

\section{A コロイド状液の調製}

$$
\begin{array}{cr}
\text { 着色メタタリル酸メチルエステル } & 100 \mathrm{cc} \\
\text { エチルエステル } & 100 \mathrm{cc} \\
\text { 過酸化ベンゾイル } & 7.4 \mathrm{~g}
\end{array}
$$

以上の割合で混合し，温浴または注意しながら直火で

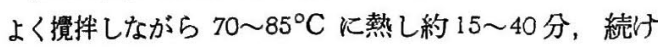
ると次第に重合してアメ状になつてくるので冷却後粘度 が增すことを考慮に入れて適当なところで泠却する。こ のコロイト状夜は冷却した場所では数ヶ月保存できる。

\section{B 注入液の調製}

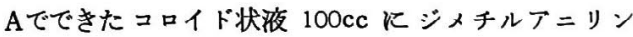
$1 \mathrm{cc}$ を混せ直ちに目的血管に注入器により注入する（注 入器には特殊のるのを要しないがかなりの圧で注入する ので注入嘴管に工夫を加党なくてはならない).

\section{3. 実験成縤}

正常犬の 頸動脈走行は図 9 写真 4 の如くで 2)6)13)30),

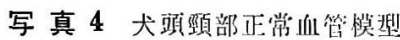

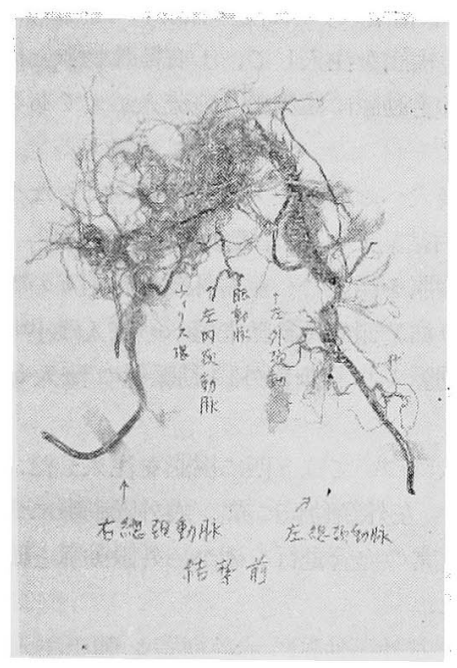

大体人間のものと類似しているが，異なる点として，1） 犬の椎骨動脈は右鎖骨下動脈より出て途中で左右椎骨動 脈に分れる．2）内頸動眽は頭蓋内に入り直ちに外頸動 脈之吻合する。この吻合血管はすぐに2本に分技し一本 は中硬膜動脈，も5一本は外眼動脈の挍となる. 写真 3 参照.この二点が著るしく異なる点であつた。

30 日後の副血行を知るために外頸動脈絬禁後 30 日犬 5 匹に樹脂を注入した。 その結果を個々のもので見てみ ると次の如くである.

No. 3 健側外頸動脈より結禁側外頸動脈への 吻合を知るために 健側左に强圧注入を行なつ た (左側外頸動脈に赤, 右側に青注入). そし て、(1)結禁側右外頸動派末梢に健側よりの注入 が大であつた. (2)結紮側の結紮部に近い部位に は同側外㛲動脈上り注入した青色樹脂が良く入 つていた. (3)結禁側頸椎動脈を後頭動脈の沕合

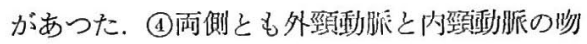

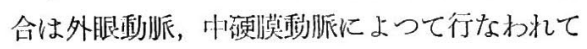
いた。

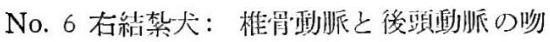
合を知るために左総项動脈に督色樹脂注入, 右

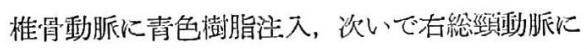
赤色樹脂注入を行な括らとしたがすでに右総頸 動脈に樹脂が流入して不能ざつた。そして，(1)

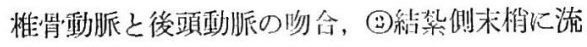
入大, (3)絬紮側節骨動脈と外眼動脈, 眼動脈と 外眼動脈の吻合, (4)両側外頸動脈上りの中硬膜 
動脈，外眼勳挀と内頸動脈の㕧合を認めた。

No. 12 右結紮犬：右椎骨動脈化青色樹脂，左総頸 動脈に赤色樹脂を注入して, (1)右椎䯈動脈と後頭動脈の 吻合と，(2)舌動脈に健側よりの流入が大であることを認 めた。

結紮直後犬への樹脂注入は一匹のみに行なつた。

No. 5 右結紮犬：右総頸動哌清色樹脂，左総頸動 脈に赤色樹脂を注入し，左右外頸動脈相互の吻合を見た が健側より結紮側外頸動脈末梢への流入は小で，また絬 禁側総頸動脈上り結紮側外頸動脈への流入も 少なかつ た.

未処置犬については 3 匹に樹脂を注入した.

No. 1：左外頸動脈に赤，右外頸動脈に青色樹脂を 注入して正常の血管走行を確かめ外眼動脈と眼動脈の吻 合も認めた。

No. 7：左外頸動脈に 赤色樹脂を強止注入し，どこ 迄反刘側結紮側外頸動脈に流入するかを調べた，そして (1)健側外頸動脈上り結焚側外頸動脈一の吻合は非常に少 ない. (2)内頸動脈より外眼動脈または中峺膜動脈を通つ て外頸動脈と吻合する血管がすでに重要な役割を示すこ とが判つた.

写真 5 外頸動脈之内钼動脈間の吻合枝
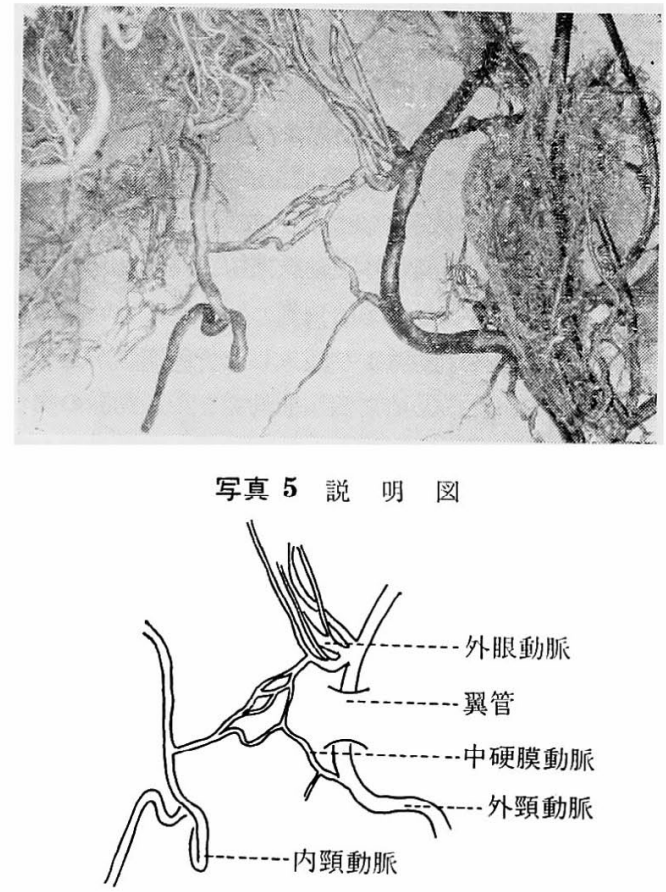

写真 6 健側外䫌動脈よりの流入が大である

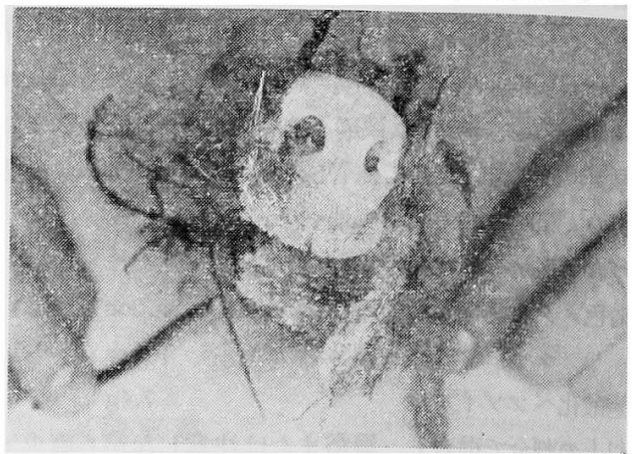

写真 7 節骨動脈一外一外眼動脈 の吻合

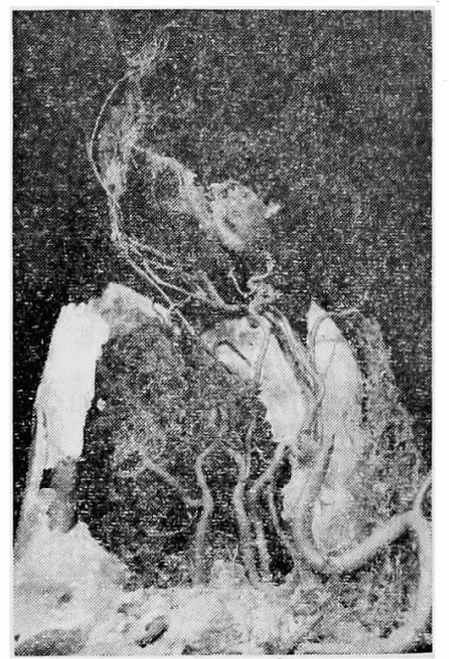

写真 7 説 明 図

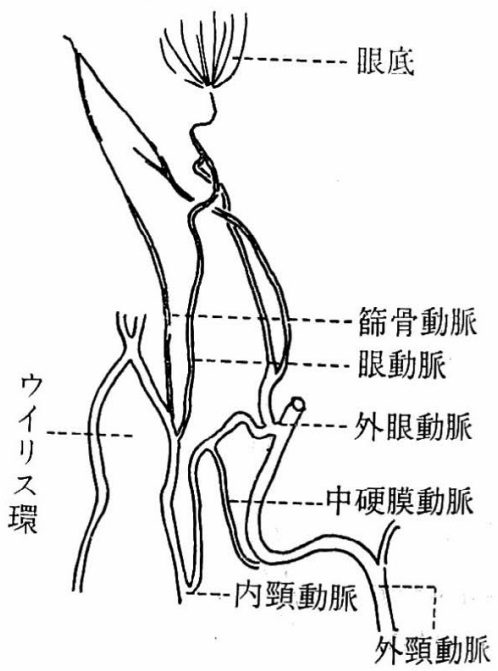


写真 8 後頭動脈椎骨動脈の吻合

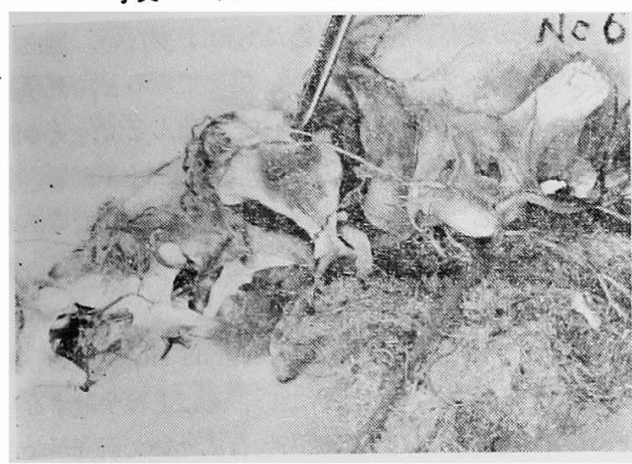

図 10 犬の血管吻合図

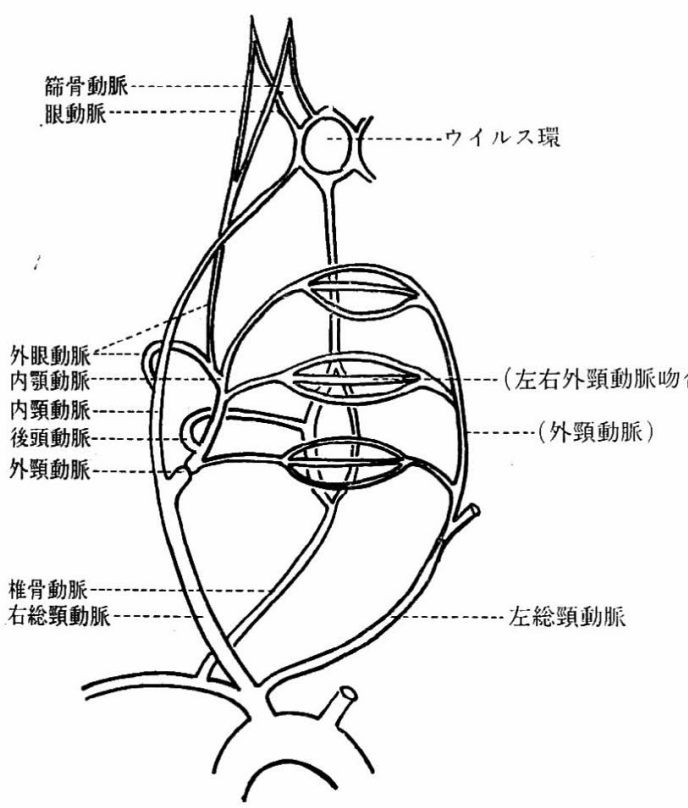

4. 小 括

以上犬の血管立体模型より外頸動脈結紮部の末梢任流 を特もに維持するものは外眼動脈, 中硬膜動脈之内頸㚪 哌との吻合技であり（写真 5), 外頸動脈相互の吻合も 次第に密になり (写真 6), 眼動脈 $\rightarrow$ 外眼動脈, 篩骨動 脈 $\rightarrow$ 外眼動脈 (写真 7), 椎骨動脈 $\rightarrow$ 後頭動脈 (写真 8) 等の吻合血管も次第に太くなり，血流維特に関与してく ることが判つた (10 図参照).

\section{V. 皮膚温測定による実験}

外頸動脈結紮前後の耳垂部温度を温度サーミスター22) により人間の 4 例に行つた. 鈴木 ${ }^{26)}$ は外頸動脈結紮後
の皮層温を一例測定し変化なしと述べているが，著者の 例ではいずれも結紮侧皮膚温は集側に比して低下し，乙 して5日以内に回復した例はなかつた。1 例のみ14日 後に回復しているが, 温度計のみで血行回復をみるのは 種々の条件上り涠理な上らに思われたので以後の䒠騟は 中止した.

\section{VI. 考案}

外頸動脈結紮は從来，耳鼻咽喉科領域，頭頸部領域の 手術の際に出血量を節約する目的で行なわれ，ぬた鼻出 血, 術後の出血, 外傷などの場合に止血の目的で行なわ れてきた．そして最近になりその応用が次第に広く行な われるよらになつてきた。たと流尾 ${ }^{31)}$ は Epilepsie に対して外頸動脈を結紮することにより両側の内頸動脈 の秃行量を增さしめて治療の目的を達成する方法を考案 し, また吉田 ${ }^{33)}$ ， Kuster, 星野らは癌に対して発充を 抑制する目的で外頸動脈を結紮し，放射線療法の効果を 上げようと試みた。また加藤 ${ }^{16)}$ は外頸動脈欠損症，前 大動脈栓塞症, 喘息, 狭心症などの手術的治療の際に外 頸動脈結紮術を作用して好結果を得ている．以上述べた ように種々の疾患への外頸動脈結禁の応用は，いずれも 外頸動脈を結紮すれば，その部分より末梢の血流，血行 は停止または減少し，長時間その効果が持続するとい う前提の下に考えられた方法である。しかし果してこの 前提が正しいものかどらか，この点について実験的に証 明した文献を見出すことができない，たた人々は繦釦的 におよそを知つているた゚けであり，推測するに止まつて いるだけである。一般的にいつて外頸動脈結禁の効果は 満足すべきものであろらと思われる，しかし滕森》の文 献によると，Tabb, schall, Schucknecht らはその意 義をあまり認めていないという．その他文献的にも同様 のことが散見される．たと学ば鈴木 ${ }^{26)}$ のように一側外 頸動脈結紮のみでは止血せず，止むを得ず両側外頸動脈 を結紮した例や，A． wolferman ${ }^{32)}$ その他のように外 頸動脈結紮のみでは止血せず，前篩骨動脈結紮を同时に 行なつて止血せしめた例, 名越 ${ }^{21) の よ う に ~}$ 結紮せざるを得なかつた例，その他かなりの数にのぼつ ている. その原因については色々といわれており，1） 血管の奇形による，2）内頸動脈より外頸動脈への吻合, 3）外頸動脈相互の吻合，4）外頸動脈中枢より結紮部末 佾への吻合などについて述べられている. 何故止血しな いのであろらか. 曰く吻合, 曰く血管の奇形によると説 明されているが，ではその血行回復がどこから，いつ頃 に再建されてくるものだろらか. この点に関する文献は 
意外に少なく，わずかに数人がこの問題について孝え意 見を述べているに過ぎない，そしてその回復の時期につ いても諸説まちまちではつきりしない，例をあげると， Johnson, Foster ${ }^{14)}$ は結紮後の副血行は 5 日以内に, 又 $\mathrm{Abraham}{ }^{3}$ ) は数日内に 確立すると経駼的に推定し ているし，吉田 ${ }^{33)}$ は結禁後の再手術時の綵:跧上り相当 長時間有効と考兄ている. 又松村 ${ }^{28)}$ は外頸動脈結毞後 25日頃に消失していた前額部血管を再び見出したことか ら，副血行回復の期間をこの程度と推測している．その 他中村 20), Adolph Wolfermann ${ }^{32}$ ) の上らに結杽直後 すでに多量の出血を末梢より認めたという報告は多いし 5)2123), A.J. Kuhn ${ }^{17)}$ は rapid establishment のため に結紮の効果がないことがあると述べている，小野 ${ }^{24)}$ は犬の軟口蓋の血管を実験的脈波計を使用して 観察 し, 一側総頸動脈結紮時 $66 \%$ 減少した血流量が 2 週間 後 $33 \%$ 減少まで回復した. すなわち 2 週間後に打いて 反対側外頸動脈より $60 \%$ の血液が 供給されていると述 べている.この数値をそのまを外頸動脈結紫時のものと することはできないが参考になる。

著者は乞の回復の時期を知る目的で脈波計，血厈計に よる実験を行ない, その結果, 外頸動脈結紮直後（結禁 後 $2 \sim 3$ 時間後を含む) にすでに術前上りる小さいが規 則正しい脈波を大多数例にみている。すすおち結禁直後 といえどもまたかなりの血行を有しており，耳垂の血管 は搏動しているということである，その血行量を左右脈 波波高より推測すると18 例中 3 例はすでに術前まで回 復している。

そして一日後になると血行量は更にふえ，すでに結禁 前迄回復しているのは 7 例となり，3日後で 10 例，5日 後で 11 例, 計 18 例中 11 例, 約 $60 \%$ は 5 日上内に回復し ている. 血圧を結紮前後で計測してみると, 結紮直後で さえも結紮前の $45 \%$ ～70\%の血俚を推持しているし，犬 に特いて計測した而圧も大休同様な值を示している。 と してこのことは外頸動脈でなくて総頸䎲脈を結势したと きの血行について Dorrence 4) が述べている上らに， 総頸動脈妾絬紮してもな括 50\% 程度の血行け残つてい るということ，小野が総頸動脈を絬染した後の外頸䡃脈 領域（軟口蓋）の血行はな扰 $37 \%$ 残つていると述べて いること，北村 ${ }^{18)}$ が外頸䡃脈を結紮しても動脈圧が静 脈圧程度に減ずるに過ぎないことを銘記すべきであると 述べていることなどを将え合せて與味深い，

では次にこれらの血行がどこから，どの副血行を通っ てきたものであろらか, この点について文献的に考察し
てみよう、まず外頸動脈を結皆した場合の副血行につい てであるが，総括的にまとめたものは少ない。副血行 路の個々について述べたものを集めてみると，外頸動 脈相互の吻合について述べたものが殆んどで，その他 Peguiron, M.E. ${ }^{25)}$ は動脈撮影で顔面動脈之眼動脈, 中 硬嗼動脈による顎動脈と眼動脈間の機能的吻合を確かめ ている. Spar, A.A. ${ }^{29)}$ は翼口㘿動脈之後節骨動脈の吻 合があると述べている.

脳外科方面では以前より Cavernous siuus の動静脈 瘤の治療に外頸動脈結紮を行ない，しぱしぱ失敗すると ころから内頸動脈之外頸動脈の吻合飞ついて研究がなさ れている.すなわち Marx, E. 19) は外頸動脈から中硬膜 動脈を通つて眼動脈への交通を挙げ，H. Vogelsang ${ }^{10)}$ は外頸動脈 $\rightarrow$ 顎動脈 $\rightarrow$ 眼動脈, 外頸動脈 $\rightarrow$ 側頭動脈 $\rightarrow$ 眼

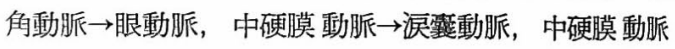
$\rightarrow$ 眼動脈の通路を挙け゚ている. 又 Padget ${ }^{27)}$ は胎生学

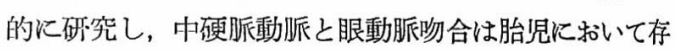
在し，大人に执いてもその潜在力を推定しているし， Hultquist ${ }^{11)}$ は 42 例の死体を調べを結果, 一生を通し て眼動脈に上る吻合機能を有していると述ぺている.

橋本 ${ }^{12)}$ は副鼻腔の血管分布について研究し, 眼動脈 分枝（前䇫骨動脈，後篩骨動脈，涙鼻枝，中間篩骨枝， 眼笳枝）はそれぞれ外頸動脈系の翼口蓋動脈分枝（外側 後鼻動脈, 中隔後鼻動脈), 顔面動脈分枝 (眼墖下動脈, 下行口蓋動脈，後上米槽動脈）と吻合をいとなんでいる と述べている.

Gandii 8) は総頸動脈結禁時の 副血行について述べて

図 11 総頸動脈結禁時の副血行路 Gandii の文献上り引用

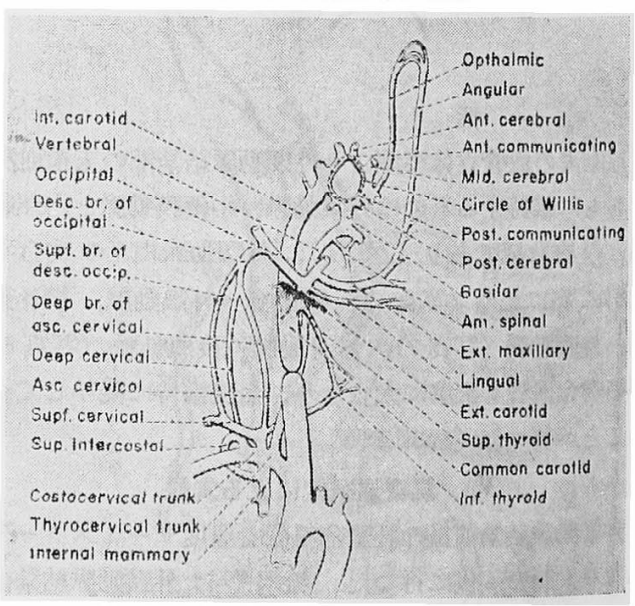




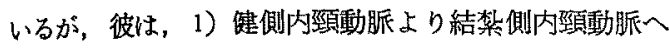
ウイリス環を通つて交通，2）結紮側椎骨動脈よりウイ リス環を通つて内頸動脈へ，3）上下甲状腺動脈の吻合，

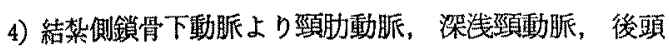
動脈をへて外頸動脈へ，5）両側外頸動脈相互の伆合， 6）眼動脈より眼角動脈をえて顔面動脈へ、以上六つの
副血行路を挙け゚ているが，外頸動脈結紮の場合では普通 上甲状腺動脈より末椬で結椒するので 1）2）3）は教慮 に入れなくても良く，4）5）6）のみが考光られる．11 因参琞.

以上個々に挙げられている副血行を総合してみると次 の表 4 の如くなる.

\section{表 4}

A）外預動脈——外頸動脈のルート

1）健側外顓動脈——結紫側外頻動脈

2）鎖骨下動脈

B）内项動眽——外幁動脈のルート

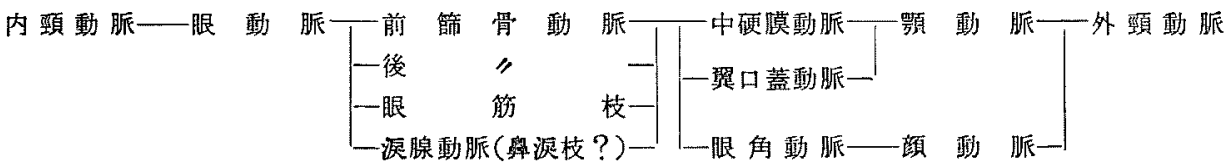

著者が犬にアクリル樹脂を注入した実験では表 5 のよ ラなルートを㒛めた。

\section{表 5}

A) 外䫫動脈——外䫑動脈のルート

1) 健㑡外䫫動脈一一結禁側外頸動脈

2）推骨動脈——後頭動脈——外顒慟脈

B）内預動脈——外欧動脈のルート

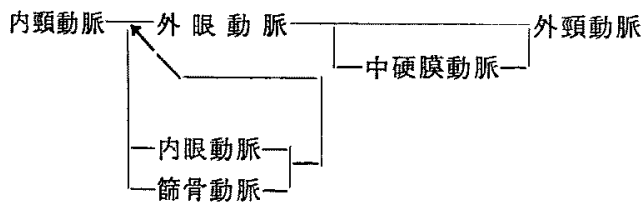

この犬に括ける副血行路を人間のそれとくらべてみる と，人の眼動眽と犬の外眼動脈がはば同様の働きをし， また人の吻合に抽鎖骨下動脈と後頭動脈の吻合は犬 の場合の椎骨動眽より後頭動脈への吻合と相似している といえる.そして血行回復の主体をなすをのは，犬の場 合外眼動脈であつて，健側外巠動脈より結禁側外動脈へ の流入は結禁直後ではまだ充分でなく次第に日を経るに したがつて大となつてくる、その他のルートすなわち内 眼動眽，節骨動脈より外眼動脈へのルート，椎骨動脈よ り後頭動眽へのルートは非常に血管が細く血行回復の主 体をなすとは考えられない。

\section{VII, 結 晤}

人間の外頸動脈結禁後の血行の時間的変化を知万ら之 乙て脈波計，血生計を用いて測定し，犬に称いてはその 他にアクリル樹脂立体血管模型を作製し副血行を知らう とした。そその結果次のような結果を得た。

1) 脈波測定に上り，約60\%以上の症例が 5 日以内に 血行を回復し，結紮直後でさ光も小ではあるが規則正し い脈波を大部分の症例に喼めた。

2）外頸動脈結紮前後の血压を人，犬で測定し結紮直 後においてさ文も静脈王程度の血王を保つていることが 判つた。

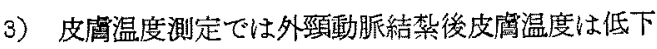
するが，温度測定のみで血行回復の時期を云々すること はできないと思われた。

4) 犬のアクリル樹脂血管模型より副血行を調べた結 果, 内頸動脈 $\rightarrow$ 外眼動脈 $\rightarrow$ 外頸動脈のルートが血行回復 の主体をなし，ついで健側外頸動脈より結森側外頸動脈 へ流入するものであることを確かめた，そして人の場合 る主な副血行路は反对側外頸動脈からのもの，眼動脈上 り外頸動脈一流入するもの，浅深頸動脈より後頭動脈を えて外頸動脈に流入する三つのルートが主なるのである らと述べた。

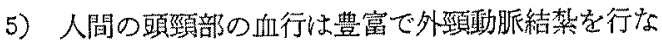
つてもな扣静脈程度の血压，血行と保つており，その回 
復もかなり早い時期，大体 5 日以内と思われるので，外 项溗脈結禁の效果に過大の期待をかけてはならないこと を強調した。

$$
\text { 文献 }
$$

1) 青木卢章, 吉村正也, 久田太郎：合成樹脂注入法 による鏟型立体標本の作製法特に気管支，気管支動脈並 びに肺動脈飞就いて，日本医師会都琵，32；695，1939. 2）相沢豊三，海塚久志： $\mathrm{N}_{2} \mathrm{O}$ 法に上る脳循環研究の 動物実験について，呼吸之循裐，5；229，1957。 Abrahams, B.H.: Ligation of the External Carotid Artery for Persistent Nasal Hemorrhage. Arch. Otholaryng., 8; 29, 1928. 4) Dorrance, J.: Ligation of the Great Vessel of the Neck. Ann. Surgery, 99；721，1934.5) 今井英雄：士舅咽㬋科項域 の局所止血儿関与る研究，日耳县，64；735，1961.

6) Ellenberger, W., \& H. Baum.: Handbuch der vergleichender Anatomie der Haustiere. 366, 1921. 7）藤森啺路：尰㴦の出血及び止血，a舅腔及び副察腔，

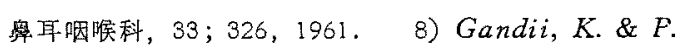
Oppenheim.: Emergency Carotid Ligation. Arch. Otolaryng., 75; 451, $1962 . \quad 9)$ Hertzman, A.B. \& J.B. Dillon.: Selective Vascular Reaction Patterns in the Nasal Sertum and Skin of the Exteremities and Head. Am. J. Physiol., 127; 671, 1939. 10) Vogelsang, H.: Über eine angiographisch selten nachzuweisende Anastomose zwischen den A. carotis interna-und $\mathrm{dm} A$. carotis externa-Kleislauf. Der Nervenarzt.: $32 ; 518,1961$.

11) Hultquist: Uber Thrombose und Embolie der Arteria carotis, Jena 1942. 12) 橋本泰彦：副奥腔の血管分布につ いて, 耳鼻咽喉科，28；13，昭31. 13）八田稆：脳 動哌の研発，その1，その2. 医学研究，10; 1803, 1935, 1987, 眧11. 14) Johnson, M.C. and M.E.

Foster.: Ligation of the External Carotid Artery for traumatic Nasal Hemorrhage. Ann. Otol. Rhin. \& Laryng. 42；588，1933. 15）加藤秀焳：反射光 電式 Plethysmography に上る下妇介粘膜血行の臨床 的研究，日耳率，68；305，1965.16）加藤萃一：左

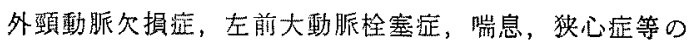
治療症例, 日本外科学会䧴誌，65；1219，1964.

A.J. Kuhn.: Ligation of Both External Carotid Arteries for Control of Epistaxis. A.M.A. Arch. Otolaryng., 62；130，1955. 18）北村武：後藤敏郎

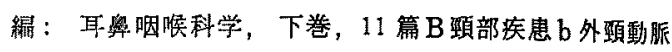
結紫，医学畫院，東京，1960，1442面. 19) Marx, E.: An Arteriographic Demonstration of Collaterals Between Internal and External Carotid Arteries. Acta. Radiol., Stockh., 31; 155, 1949.

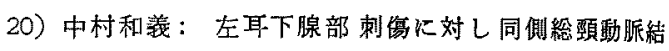
紫を行元る1 例，蹦床外科，9；33，1954。21）名越

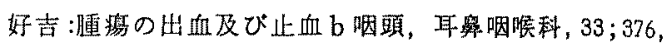
1961.22）大島良雄監修: 医学者のためのエレクト

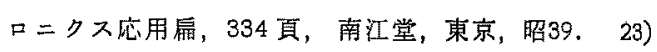
Oppenheim, H.: Surgical Interruption of the An. terior Ethmoidal Artery in Severe Epistaxis. Arch. Otolaryng., 56；448，1952. 24）小野文孝：犬の㜞 口蓋の血行状態汇関する実験的研究, 日耳鼻会報（総会 号）学術滕演嫾演録，69；34，昭41。25）Peguiron， M.E.: A propos de la ligature bilaterale de la caroride externe Presentation de deux cas personnels. Pract. oto-rhino-laryng., 23; 177, 1961. 26)

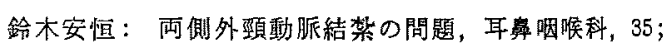
385, 1962. 27) Padget, D.H.: Development of Cranial Arteries in Human Embryo. Contributions to Embryology, Washington. 32; 205, $1948 . \quad 28$ )

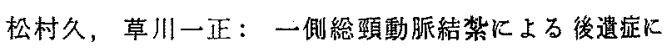
ついて, 耳鼻臨床, 45；434，1952. 29) Spar, A.A. and O.E. Hallberg: Severe Epistaxis and Its Ma. nagement. Report of 11 Cases in which the External Carotid Artery was ligated. Ann. Otol. Rhin. \&. Laryng., $56 ; 141,1947.30)$ 斉藤吉正：脳血行 遮断についての実歌的研究，熊本医学会绫，33;1220， 1959. 31) 高尾嘉輝：外頸動頸結禁術の実験的研究 並びに臨床的応用, 名古星医学, 68; 隍時号 64, 1954. 32) Wolferman, A. and F.P. Dwyer.: Unilateral and Bilateral Ligation of the External Carotid for Epistaxis. A.M.A. Arch. Otolaryng. 62; 310, 1955. 33) 吉田太助：顔部恶性腫瘍飞対する外頚動脈結柇の 治嶛的価值飞ついて，大日耳率，45；1489，1939.

稿を終るに臨文御指導御校閲を腸わつた恩師岩本 诊之亟教授に梁く感謝いたします。

本論文の要旨は第 17 回日本医学会絵会, 第 68 回 日耳鬼学会総会に扣いて報告した。

（原稿到着 $=$ 昭和 $42,4.6$ 日一急載） 